\title{
Editorial: Natural Antibodies in Health and Disease
}

\author{
Ana Maria Hernandez ${ }^{1 *}$ and Nichol E. Holodick ${ }^{2 *}$ \\ ${ }^{1}$ Natural Antibodies Group, Tumor Immunology Division, Center of Molecular Immunology, Havana, Cuba, ${ }^{2}$ Department of \\ Biomedical Sciences, Center for Immunobiology, Western Michigan University Homer Stryker MD School of Medicine, \\ Kalamazoo, MI, United States
}

Keywords: natural antibodies, B cells, B-1 cells, antibodies, natural antibodies repertoire

\section{Editorial on the Research Topic}

\section{Natural Antibodies in Health and Disease}

Natural antibodies (NAbs) are most commonly defined as immunoglobulins present in the absence of exogenous antigen stimulation. In fact, numerous groups have demonstrated the presence of NAbs in both specific pathogen-free and germ-free mice (1-3). These NAbs provide immediate protection against infection while the adaptive arm of the immune system mounts a specific and long-lasting response. Beyond immediate protection from infection, NAbs have been shown to play various functional roles in the immune system, which include clearance of apoptotic debris (Gronwall et al.), suppression of allergic responses $(4,5)$, regulation of B cell responses (6), selection of the B cell repertoire $(7,8)$, protection from cancer $(9,10)$, regulation of B cell development [Baumgarth; $(7,11)]$, and protection against atherosclerosis $(12-15)$. These various functions of NAbs are afforded by their reactivity, which is broad, cross-reactive, and shown to recognize evolutionarily fixed epitopes present in foreign antigens [Gronwall et al.; (16-21)]. Furthermore, NAbs have unique characteristics that also contribute to their functional roles and set them apart from antigen-specific antibodies. Such characteristics include germline structure (lacking non-templated nucleotides and little to no somatic hypermutation) and a restricted repertoire (16, 22-24).

Determining and subsequently examining the B cells producing NAbs have been the subject of intense investigation since the early 1980s despite NAbs being studied since the late 1960s. NAb producing B-1a cells were first identified in mice and characterized by surface expression of $\mathrm{CD}^{+}$, $\operatorname{IgM}^{\text {high }}, \operatorname{IgD}^{\text {low }}, \mathrm{CD} 19^{\text {high }}, \mathrm{B} 220^{\text {low }}, \mathrm{CD} 23^{-}$, and $\mathrm{CD} 43^{+}(25)$, which contrasts with the surface phenotype of follicular B-2 cells: CD5 ${ }^{-}, \mathrm{IgM}^{\text {low }}, \mathrm{IgD}^{\text {high }}, \mathrm{CD} 19^{+}, \mathrm{B} 220^{+}, \mathrm{CD}_{2} 3^{+}$, and $\mathrm{CD} 43^{-}$. Studies have demonstrated that B-1a cells are found in the peritoneal cavity, pleural cavity, spleen, bone marrow, lymph nodes, and blood of mice (26). Furthermore, various subsets of B-1a cells have been identified and include those expressing PD-L2 (PD-L2 $\left.{ }^{+/-}\right)(27,28)$, CD25 (CD25+/-) (Tumang et al.), CD73 $\left(\mathrm{CD} 73^{\mathrm{hi} / \mathrm{lo}}\right)(29)$, and PC-1 (PC-1 $\left.{ }^{\mathrm{hi} / \mathrm{lo}}\right)$. Throughout the many years of B-1a cell investigation, it has been shown that not all subsets of murine B-1a cells secrete NAbs. This has important implications when investigating the source of protective and/or pathogenic NAbs.

More recently, focus has been given in determining the subset of B cells in humans capable of producing NAbs. Early studies in humans focused on $\mathrm{CD}^{+}$peripheral B cells (30-33) and CD5-CD45RAlo B cells (34). More recently, attempts to refine the human NAb producing B cell subset have generated a new phenotypic definition: $\mathrm{CD} 20^{+} \mathrm{CD} 27^{+} \mathrm{CD} 43^{+} \mathrm{CD} 70^{-} \mathrm{CD} 38^{\text {mod }}(35,36)$. Interestingly, most of these cells express CD5. Further investigation is still required in the human system to determine whether other subsets of NAb producing B cells exist and the location of such subsets beyond peripheral blood.

Many aspects of NAbs and the cells generating them have yet to be studied in great detail: the reactivity and function of NAbs in health and different diseases, the behavior of the NAb repertoire 
with increasing age, the regulation of NAb production and autoreactivity, the ways to specifically activate NAbs producing B-1 cells with desired specificities, and the characteristics of human NAbs, among others. This Frontiers research topic aimed to further investigate how NAbs are regulated, the cells that generate NAbs, and the roles NAbs play in maintaining health and/or leading to disease.

The 16 articles presented in this research topic explore a wide range of topics pertaining to NAbs (and the cells that produce them) in health and disease. These papers investigate the specificity of NAbs [Cruz-Leal et al.; Vale et al.; Zhang et al.], the function of NAbs [Pedersen et al.; Kohler et al.; Rothstein; Saha et al.], the cells producing NAb [Baumgarth; Popi et al.; Kaku et al.], and/ or the role NAbs and/or NAb producing cells play in leading to disease [Wang et al.; Holodick et al.; Lobo; Wolfram et al.; Zhu et al.]. In addition, we include a perspective article aiming to start discussion and investigation into the definition of NAbs

\section{REFERENCES}

1. Bos NA, Meeuwsen CG, Wostmann BS, Pleasants JR, Benner R. The influence of exogenous antigenic stimulation on the specificity repertoire of background immunoglobulin-secreting cells of different isotypes. Cell Immunol (1988) 112:371-80. doi:10.1016/0008-8749(88)90306-1

2. Haury M, Sundblad A, Grandien A, Barreau C, Coutinho A, Nobrega A. The repertoire of serum IgM in normal mice is largely independent of external antigenic contact. Eur J Immunol (1997) 27:1557-63. doi:10.1002/ eji.1830270635

3. Savage HP, Yenson VM, Sawhney SS, Mousseau BJ, Lund FE, Baumgarth N. Blimp-1-dependent and -independent natural antibody production by B-1 and B-1-derived plasma cells. J Exp Med (2017) 214:2777-94. doi:10.1084/ jem.20161122

4. Kearney JF, Patel P, Stefanov EK, King RG. Natural antibody repertoires: development and functional role in inhibiting allergic airway disease. Annu Rev Immunol (2015) 33:475-504. doi:10.1146/annurev-immunol-032713-120140

5. Patel PS, Kearney JF. Neonatal exposure to pneumococcal phosphorylcholine modulates the development of house dust mite allergy during adult life. J Immunol (2015) 194:5838-50. doi:10.4049/jimmunol.1500251

6. Boes M, Esau C, Fischer MB, Schmidt T, Carroll M, Chen J. Enhanced B-1 cell development, but impaired IgG antibody responses in mice deficient in secreted IgM. J Immunol (1998) 160:4776-87.

7. Nguyen TT, Elsner RA, Baumgarth N. Natural IgM prevents autoimmunity by enforcing B cell central tolerance induction. J Immunol (2015) 194:1489-502. doi:10.4049/jimmunol.1401880

8. Freitas AA, Viale AC, Sundblad A, Heusser C, Coutinho A. Normal serum immunoglobulins participate in the selection of peripheral B-cell repertoires. Proc Natl Acad Sci U S A (1991) 88:5640-4. doi:10.1073/pnas.88.13.5640

9. Vollmers HP, Brandlein S. Natural antibodies and cancer. N Biotechnol (2009) 25:294-8. doi:10.1016/j.nbt.2009.03.016

10. MadiA,Bransburg-ZabaryS, Maayan-MetzgerA,DarG,Ben-JacobE,CohenIR. Tumor-associated and disease-associated autoantibody repertoires in healthy colostrum and maternal and newborn cord sera. J Immunol (2015) 194:5272-81. doi:10.4049/jimmunol.1402771

11. Nguyen TT, Klasener K, Zurn C, Castillo PA, Brust-Mascher I, Imai DM, et al. The IgM receptor FcmuR limits tonic BCR signaling by regulating expression of the IgM BCR. Nat Immunol (2017) 18:321-33. doi:10.1038/ni.3677

12. Tsiantoulas D, Diehl CJ, Witztum JL, Binder CJ. B cells and humoral immunity in atherosclerosis. Circ Res (2014) 114:1743-56. doi:10.1161/ CIRCRESAHA.113.301145

13. Zhang M, Alicot EM, Chiu I, Li J, Verna N, Vorup-Jensen T, et al. Identification of the target self-antigens in reperfusion injury. J Exp Med (2006) 203:141-52. doi:10.1084/jem.20050390
(Holodick et al.). With the plethora of established and new data on NAbs and NAb producing cells, it is clear our traditional definition of such antibodies might need to be refined or bolstered. Overall, this collection of articles adds to the NAb literature in a thoughtful and hopefully thought-provoking way. We thank all of the authors for contributing their work to this ebook, which will inspire many new lines of investigation into the structure, generation, and function of NAbs in health and disease.

\section{AUTHOR CONTRIBUTIONS}

Both authors contributed equally to the writing of this editorial.

\section{ACKNOWLEDGMENTS}

We thank Dr. Thomas L. Rothstein for his helpful review of this editorial and discussions on the subject of natural antibodies.

14. Binder CJ, Shaw PX, Chang MK, Boullier A, Hartvigsen K, Horkko S, et al The role of natural antibodies in atherogenesis. J Lipid Res (2005) 46:1353-63. doi:10.1194/jlr.R500005-JLR200

15. Binder CJ, Silverman GJ. Natural antibodies and the autoimmunity of atherosclerosis. Springer Semin Immunopathol (2005) 26:385-404. doi:10.1007/ s00281-004-0185-z

16. Feeney AJ. Predominance of the prototypic T15 anti-phosphorylcholine junctional sequence in neonatal pre-B cells. J Immunol (1991) 147:4343-50.

17. Brundish DE, Baddiley J. Pneumococcal C-substance, a ribitol teichoic acid containing choline phosphate. Biochem J (1968) 110:573-82. doi:10.1042/ bj1100573

18. Shaw PX, Horkko S, Chang MK, Curtiss LK, Palinski W, Silverman GJ, et al. Natural antibodies with the T15 idiotype may act in atherosclerosis, apoptotic clearance, and protective immunity. J Clin Invest (2000) 105:1731-40. doi:10.1172/JCI8472

19. Binder CJ, Horkko S, Dewan A, Chang MK, Kieu EP, Goodyear CS, et al. Pneumococcal vaccination decreases atherosclerotic lesion formation: molecular mimicry between Streptococcus pneumoniae and oxidized LDL. Nat Med (2003) 9:736-43. doi:10.1038/nm876

20. Chen Y, Park YB, Patel E, Silverman GJ. IgM antibodies to apoptosis-associated determinants recruit $\mathrm{Clq}$ and enhance dendritic cell phagocytosis of apoptotic cells. J Immunol (2009) 182:6031-43. doi:10.4049/jimmunol.0804191

21. Chou MY, Fogelstrand L, Hartvigsen K, Hansen LF, Woelkers D, Shaw PX, et al. Oxidation-specific epitopes are dominant targets of innate natural antibodies in mice and humans. J Clin Invest (2009) 119:1335-49. doi:10.1172/JCI36800

22. Tornberg UC, Holmberg D. B-1a, B-1b and B-2 B cells display unique VHDJH repertoires formed at different stages of ontogeny and under different selection pressures. EMBO J (1995) 14:1680-9.

23. Kantor AB, Merrill CE, Herzenberg LA, Hillson JL. An unbiased analysis of $\mathrm{V}(\mathrm{H})-\mathrm{D}-\mathrm{J}(\mathrm{H})$ sequences from B-1a, B-1b, and conventional B cells. J Immunol (1997) 158:1175-86.

24. Mercolino TJ, Arnold LW, Hawkins LA, Haughton G. Normal mouse peritoneum contains a large population of Ly-1+ (CD5) B cells that recognize phosphatidyl choline. Relationship to cells that secrete hemolytic antibody specific for autologous erythrocytes. J Exp Med (1988) 168:687-98. doi:10.1084/ jem.168.2.687

25. Baumgarth N. B-cell immunophenotyping. Methods Cell Biol (2004) 75:643-62. doi:10.1016/S0091-679X(04)75027-X

26. Baumgarth $\mathrm{N}$. The double life of a B-1 cell: self-reactivity selects for protective effector functions. Nat Rev Immunol (2011) 11:34-46. doi:10.1038/nri2901

27. Zhong X, Tumang JR, Gao W, Bai C, Rothstein TL. PD-L2 expression extends beyond dendritic cells/macrophages to B1 cells enriched for $\mathrm{V}(\mathrm{H}) 11 / \mathrm{V}(\mathrm{H}) 12$ and phosphatidylcholine binding. Eur JImmunol (2007) 37:2405-10. doi:10.1002/eji.200737461 
28. Zhong X, Lau S, Bai C, Degauque N, Holodick NE, Steven SJ, et al. A novel subpopulation of B-1 cells is enriched with autoreactivity in normal and lupus-prone mice. Arthritis Rheum (2009) 60:3734-43. doi:10.1002/art.25015

29. Kaku H, Cheng KF, Al-Abed Y, Rothstein TL. A novel mechanism of B cell-mediated immune suppression through CD73 expression and adenosine production. JImmunol (2014) 193:5904-13. doi:10.4049/ jimmunol.1400336

30. Casali P, Notkins AL. CD5+ B lymphocytes, polyreactive antibodies and the human B-cell repertoire. Immunol Today (1989) 10:364-8. doi:10.1016/0167-5699(89)90268-5

31. Antin JH, Emerson SG, Martin P, Gadol N, Ault KA. Leu-1+ (CD5+) B cells. A major lymphoid subpopulation in human fetal spleen: phenotypic and functional studies. J Immunol (1986) 136:505-10.

32. Kipps TJ, Fong S, Tomhave E, Chen PP, Goldfien RD, Carson DA. Highfrequency expression of a conserved kappa light-chain variable-region gene in chronic lymphocytic leukemia. Proc Natl Acad Sci U S A (1987) 84:2916-20. doi:10.1073/pnas.84.9.2916

33. Casali P, Burastero SE, Nakamura M, Inghirami G, Notkins AL. Human lymphocytes making rheumatoid factor and antibody to ssDNA belong to Leu-1+ B-cell subset. Science (1987) 236:77-81. doi:10.1126/ science. 3105056
34. Kasaian MT, Ikematsu H, Casali P. Identification and analysis of a novel human surface CD5- B lymphocyte subset producing natural antibodies. J Immunol (1992) 148:2690-702.

35. Griffin DO, Holodick NE, Rothstein TL. Human B1 cells in umbilical cord and adult peripheral blood express the novel phenotype CD20+ CD27+ CD43+ CD70. J Exp Med (2011) 208:67-80. doi:10.1084/jem.201014992011113c

36. Quach TD, Rodriguez-Zhurbenko N, Hopkins TJ, Guo X, Hernandez AM, $\mathrm{Li}$ W, et al. Distinctions among circulating antibody-secreting cell populations, including B-1 cells, in human adult peripheral blood. J Immunol (2016) 196:1060-9. doi:10.4049/jimmunol.1501843

Conflict of Interest Statement: The authors declare that the research was conducted in the absence of any commercial or financial relationships that could be construed as a potential conflict of interest.

Copyright $(2) 2017$ Hernandez and Holodick. This is an open-access article distributed under the terms of the Creative Commons Attribution License (CC BY). The use, distribution or reproduction in other forums is permitted, provided the original author(s) or licensor are credited and that the original publication in this journal is cited, in accordance with accepted academic practice. No use, distribution or reproduction is permitted which does not comply with these terms. 